\title{
STUDY OF SOME FIELD INDICATORS FOR THE CHISEL PLOW BY USING LOCALLY DEVELOPED SHARES
}

\author{
Saad A. A. Al Rijabo ${ }^{1}$ \\ Basheer A. M. Al Nuaimi ${ }^{2}$ \\ ${ }^{1,2}$ Agriculture Mechanization Dept. College. of Agric. \& Forestry / Mosul \\ University /Iraq \\ E-mail: saad21955mech@gmail.com
}

\begin{abstract}
A field experiment was conducted in one of the fields in Nineveh Governorate, in soil texture was clay silty loam, under the axial sprinkler system, where the research included studying the effect of (two levels of soil moisture (13$15 \%),(17-19 \%)$, two depth of tillage $(12-14 \mathrm{~cm})$ and $(15-17 \mathrm{~cm})$, and three types of chisel plow-share (conventional share, the spearhead and the severed share)), on the following field indicators (draft force, soil adhesion force, the tillage appearance through (number of clods with a diameter larger than $7.5 \mathrm{~cm}$ ) and the vertical deviation ratio to tillage depth). This experiment was implemented with split-split plot under randomized complete block design (RCBD) with three replicates. The results showed that the lowest draft force, adhesion strength, number of clods, and the lowest vertical deviation ratio to tillage depth were recorded in the soil moisture content (13-15\%), the depth (12-14) $\mathrm{cm}$ recorded the lowest draft force, adhesion strength and a number of clods, while it outperformed depth (15-17) $\mathrm{cm}$ in obtaining the lowest ratio of vertical deviation, as the severed share outperformed in obtaining the lowest draft force, adhesion strength and a number of clods, while the spearhead share outperformed in obtaining the lowest ratio of vertical deviation, achieved interaction between the soil moisture content (13-15\%) and the depth (1214) $\mathrm{cm}$, the lowest draft force, adhesion strength and a number of clods, while the interaction between the soil moisture content (13-15\%) and depth (15-17) $\mathrm{cm}$ achieved the lowest ratio of vertical deviation.
\end{abstract}

Keywords : chisel plow, cutting share, soil adhesion, draft force, vertical deviation.

Received: 17 / 6/2020 , Accepted : 3 / 8 /2020

\section{INTRODUCTION}

The chisel plow is one of the most prevalent plows. It has many characteristics: including the lack of power requirements compared to the invert plow. shoving and dismantling the soil at various depths and does not overturn it with little coverage of plant remains. Also it conserves the surface layer of the field in which fertility is concentrated. So it leaves the soil surface corrugated. Thus this case helps to prevent erosion by wind or water. Finally, it improvs water penetration into the soil (Mustafa and Al-Sahar, 2007). The possibility of using different types of shares for the chisel plow through modulation and development in different types

*Part of M.Sc. thesis submitted by the second author. 
of soils should achieve reduced friction with the soil and lowest draft force and facilitate the molecules flow of soil particles on the surface of the share (Alrijabo and Kashmola, 2013). Manuwa and Ademosun (2007) and Jebur and Alsayyah (2017) found in their study of the influence of soil moisture content on the draft force, that the draft force increases as the soil moisture content increases, especially in clay soils. Increasing the depth of tillage of the chisel plow can lead to an increase in the draft force clearly (Al-suhaibani and Gali, 2010; Kim et al., 2020) where they observed when the speed was fixity, the draft force increased by a clear increase when increasing the depth of tillage from (11 to 19) $\mathrm{cm}$. Al-Talabani et al. (2015) explained in a field study that the roughness of tillage appearance is directly proportional to the increase in the depth of tillage because the sub-surface soil has a higher density and hardness than surface soil. Jasim and Saadoon (2016) also explained that the decrease in for soil moisture content from (19 to $15 \%)$ reduced the number of clods with a diameter big than $10 \mathrm{~cm}$. AL-Obaidi (2018) stated in his study on assessing the performance of the chisel plow that the increase in depth of tillage led to an increase in the number of clods with a diameter big than $10 \mathrm{~cm}$, and the reason for this is that the increase in the depth of tillage leads to an increase in the volume of soil disturbed and this in turn leads to an increase in the number of clods. Al-Sheekh Ali (2018) concluded that increasing soil moisture leads to an increase in the value irregularity index of tillage depth. Abdullah and Shaheen (2018) also indicated that the increase in the depth of tillage led to a decrease in the vertical deviation ratio, so that the pressure from the plow on the soil will be greater. the degree of soil adhesion depends on its moisture, fragmentation, and the nature of the surface of the working part. when making special agricultural equipment in dealing with the soil, several measures are put into the calculation aimed at reducing adhesion because this characteristic may harm the quality of the tillage and increase the qualitative resistance to pulling (AlBanna, 1990). Al-Tai (2013) found that the depth of tillage had a significant effect on the adhesion strength, as the depth exceeded (10-12) $\mathrm{cm}$ in recording the less adhesion strength of the soil compared to the depth $(15-17) \mathrm{cm}$, and attributed the reason for this to the increase in depth leading to an increase in content moisture, so soil particles and molecules have easily. So is will be gravitated on the surface of any object on order to from constitute wrappers between it and the soil. The result is an increasing soil adhesion strength. Alrijabo and Al-Sheekh Ali (2018) found in their study that the increase in the soil moisture content of the soil led to a significant increase in the adhesion strength, as the soil moisture content (14-16\%) outperformed by recording the less significant value of the adhesion strength compared to the moisture content $(18-20 \%)$, the reason is that the water is held with the less possible force by the moist soil aggregates, and this, in turn, will affect the attraction of those molecules the surface of the working part, this will cause gravitating of praticles on the surface of the working part and the soil, and this is what also indicated (Abdullah and Ahmed, 2018). In order to obtain the best share made for the chisel plow, which penetrates the soil perfectly. Also it achieves the best positive results for the mechanical characteristics (draft force, soil adhesion, vertical deviation ratio and tillage appearance) with the selection of the most suitable soil moisture content. 
Thuas it works with these types of shares and their suitability to achieve good results for the characteristics mentioned above. Moreover knowing the best tillage depth for a suitable investigator to work with these types of manufactured shares, this research was conducted.

\section{MATERIALS AND METHODS}

The experiment was conducted in one of the agricultural fields in the village of Kharab/ district of Wana. Which is located northwest of the city of Mosul for the agricultural season (2019) in a silty loam soil texture. The area of the field actually used (1) hectares Which was planted with wheat in the previous season. The field was discriminated as level with the ground, and the field irrigation system was with axial spraying. The randomized complete block design was followed and the (splitsplit) panels method was used to conducting the experiment (Dawood and Elias, 1990), where the main panels (Main Plot) were allocated to soil moisture at two levels (13-15\%). and (17-19\%), and each main panel was divided into two secondary panels (Sub Plot), which in turn were allocated to the depth of tillage at two levels (12-14) $\mathrm{cm}$ and (15-17) $\mathrm{cm}$. Each secondary panel was divided into (subplot-sub) which was allocated to the type of manufactured share at three levels (conventional share, spearhead and severed share). That by using a fixed forward speed for all treatments $(4.72) \mathrm{km} / \mathrm{h}$, so that the experience would be $(2 \times 2 \times 3)$, i.e. it contained (12) treatments and three replicates, so that the number of experimental units becomes (36) units with an area of $(64.8) \mathrm{m}^{2}$ for the experimental unit with a length (30) meters and width (2.16) meters. The Duncan multi-range test at 0.05 probability level was used to test the significance of the differences between the mean averages. Two types of shares were designed and manufactured locally, the first is the spearhead and the second is the severed share, which was used in research in addition to the conventional share. The mechanical properties of the metal were examined in the Material Inspection Laboratory/Department of Mechanical Engineering/ University of Mosul and found to be within the permissible limits, and table (1) shows the chemical composition and mechanical properties of the metal used in the manufacturing process, as table (2) shows the specifications of these shares, and figures $(1,2,3)$ show the side, back, and front projections of shares (conventional share, spearhead share, severed share), respectively. 
Mesopotamia J. of Agric.

Vol. (48) No. (3) 2020
ISSN: 2224 - 9796 (Online)

ISSN: 1815 - 316 X (Print)

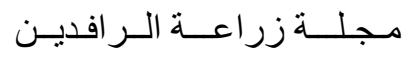

المجلد (48) العدد (3) 2020

Table (1): Shows the chemical composition and mechanical properties of the used metal

\begin{tabular}{|c|c|c|c|}
\hline \multirow{8}{*}{$\begin{array}{l}\text { Chemical } \\
\text { composition }\end{array}$} & Metal type & Ratio of components & $\begin{array}{l}\text { Metal } \\
\text { code }\end{array}$ \\
\hline & Iron & 93.16 & \multirow{11}{*}{$\begin{array}{l}1084 \\
\text { AISI }\end{array}$} \\
\hline & Carbon & 0.881 & \\
\hline & Silicone & 1.27 & \\
\hline & Manganese & 0.794 & \\
\hline & Chrome & 0.084 & \\
\hline & Molybdenum & 0.222 & \\
\hline & Tungsten & 2.84 & \\
\hline \multirow{4}{*}{$\begin{array}{c}\text { Mechanical } \\
\text { properties }\end{array}$} & Submission stress $\left(\mathrm{N} / \mathrm{mm}^{2}\right)$ & 1183.5 & \\
\hline & Tensile strength $\left(\mathrm{N} / \mathrm{mm}^{2}\right)$ & 1411.9 & \\
\hline & Elongation ratio $(\%)$ & 9.37 & \\
\hline & Hardness (HRC) & 31.14 & \\
\hline
\end{tabular}

Table (2): Specifications of the shares used

\begin{tabular}{|c|c|c|c|}
\hline Specifications & $\begin{array}{c}\text { Conventional } \\
\text { share }\end{array}$ & $\begin{array}{c}\text { Spearhead } \\
\text { share }\end{array}$ & $\begin{array}{c}\text { Severed } \\
\text { share }\end{array}$ \\
\hline $\begin{array}{c}\text { Area of pointed limp of the share } \\
\left(\mathrm{mm}^{2}\right)\end{array}$ & 900 & 1080 & 900 \\
\hline The thickness of the share $(\mathrm{mm})$ & 6 & 6 & 6 \\
\hline Share length $(\mathrm{mm})$ & 260 & 260 & 260 \\
\hline The separation angle & $69.6^{\circ}$ & $79.6^{\circ}$ & $54.2^{\circ}$ \\
\hline The penetration angle & $55.2^{\circ}$ & $50.2^{\circ}$ & $35.8^{\circ}$ \\
\hline Total share area $\left(\mathrm{mm}^{2}\right)$ & 11200 & 11760 & 11200 \\
\hline
\end{tabular}

Figure (1): The side, back and front view of the conventional share

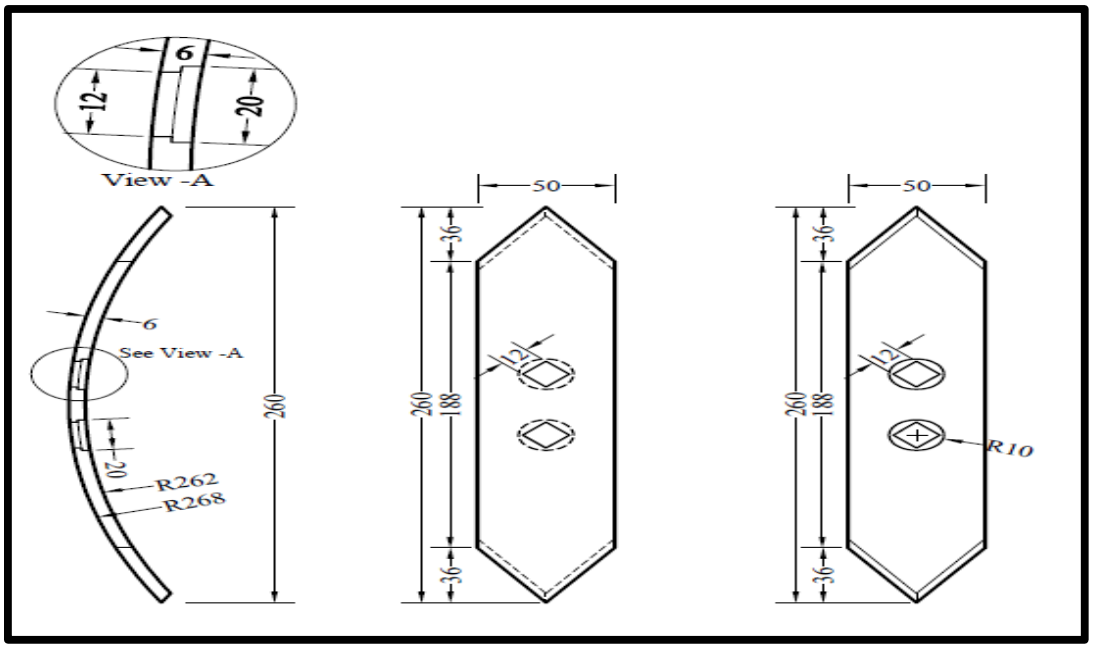


Figure (2): The side, back and front view of the spearhead share

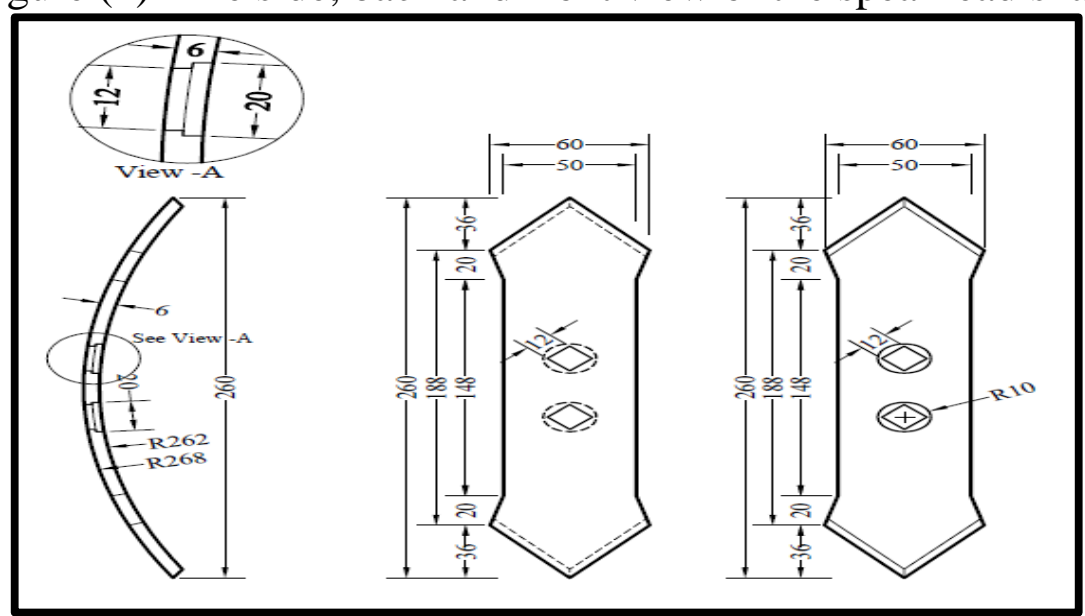

Figure (3): The side, back and front view of the severed share

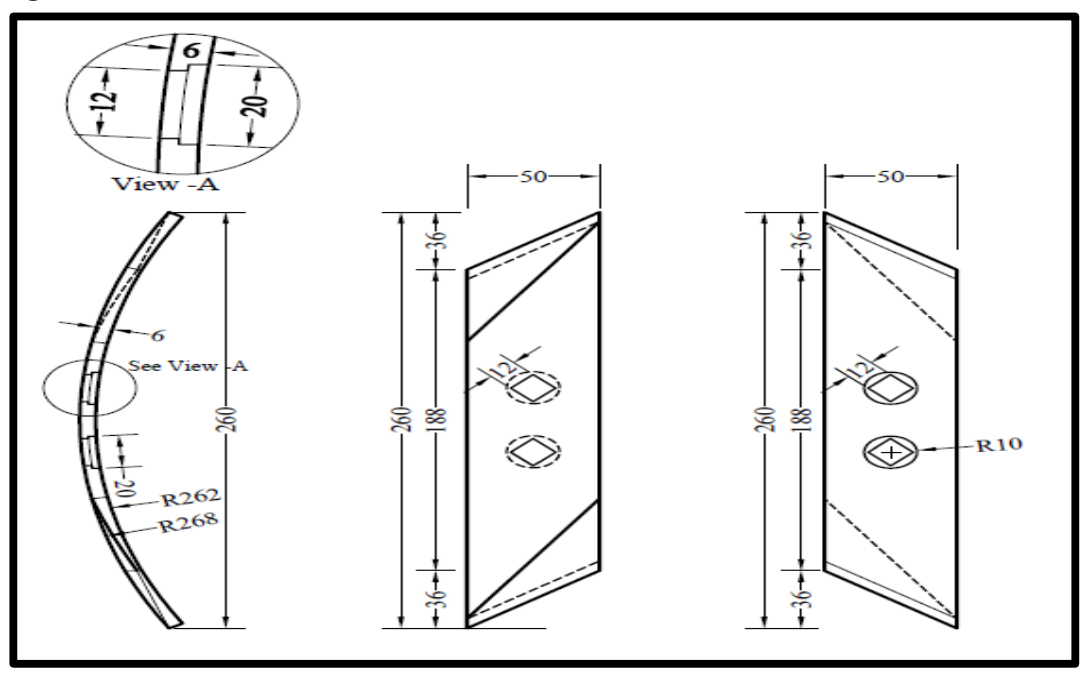

A New Holland TD95D tractor with a horse power of $98 \mathrm{hp}$ was used with a chisel plow made by the State Company for Mechanical Industries/Aliskandaryah in Babel. The following indicators were studied:

\section{1- Draft force $(\mathbf{k N})$ :}

Adai (2016) defined the draft force it: the force required to pull the load, whether it is an agricultural machine or a vehicle forward and affects the opposite direction of the tractor movement. The draft force measurement was taken directly from the mechanical dynamometer, and the draft force was calculated according to the method used by (Grisso et al., 2007) using the following equation :

$F T=F p m-F r m$

where:

FT: The force required to pull $(\mathrm{kN})$.

Fpm: Thrust force to the front tractor $(\mathrm{kN})$.

Frm: Rolling resistance to the rear tractor $(\mathrm{kN})$.

\section{2- Adhesion strength $\left(\mathrm{kN} / \mathrm{m}^{2}\right)$}


Represents the amount of soil adhesion on the surface of the share after finishing work, and is calculated according to the following equation (Al-Suhaibani and Wehbe, 1985):

$C=\frac{W S}{A} \ldots \ldots$

where:

C: Soils adhesion to the surface of the share $\left(\mathrm{kN} / \mathrm{m}^{2}\right)$.

WS: Weight of soil on the surface of the share $(\mathrm{kN})$.

A: Shared area $\left(\mathrm{m}^{2}\right)$.

3- Tillage appearance (number of clods larger than $7.5 \mathrm{~cm})\left(\mathrm{clods} / \mathrm{m}^{2}\right)$ :

A wooden frame of $0.25 \mathrm{~m}^{2}$ was used to find the number of clods whose a diameter larger than $(7.5) \mathrm{cm}$ randomly for each treatment and at the rate of four readings per repetition after tillage directly to each for soil moisture content by calculating the number of clods remaining above the sieve, and the number is multiplied by (4) to find it per square meter (Al-Talabani, 2008).

4- Vertical deviation ratio (\%):

That represents the ratio in which the plow- share deviates from the previously calibration tillage depth and this deviation is important in determining the viability of the plow work. It is calculated by the following equations (Bernacki et al., 1972):

$a s r=\sum \frac{a p}{n p} \ldots \ldots$

where:

asr: Average depth $(\mathrm{cm})$.

ap: Measured depth $(\mathrm{cm})$.

np: Number of iterations.

$\Delta a=\sqrt{\sum \frac{(a p-a s r)^{2}}{n p} \ldots \ldots}$

where:

$\Delta a$ : Mean depth deviation (cm).

$\delta a=\left(\frac{\Delta a}{a s r}\right) \times 100$

where:

$\delta a$ : Irregularity index of tillage depth (\%).

\section{RESULTS AND DISCUSSION}

1- Draft force $(\mathbf{k N})$ : Table (3) shows the recording of soil moisture content (13$15 \%$ ) the lowest significant value of draft force was (6.67) $\mathrm{kN}$ compared to the soil moisture content (17-19\%), the reason for this is due to increasing the soil moisture content of the soil increases the slippage and thus reduces the chance of the wheels driving the tractor with the soil surface, which in turn leads to an increase in the load on the rear axial of the tractor, which increases the draft force, and this is consistent with what mentioned (Manuwa and Ademosun, 2007; Jebur and Alsayyah, 2017). The depth (12-14) $\mathrm{cm}$ achieved the lowest significant value of the draft force compared to the depth $(15-17) \mathrm{cm}$, the reason for this is the increase of 
the load on the plow, which increases the value of the resistance that the plow receives, so the draft force increases, and the increase in depth it leads to an increase in the volume of soil disassembled by the plow-shares and results in an increase in the weight of the soil collected in front of the plow-shares, which leads to an increase in the draft force, as well as increasing the strength of cohesion between the soil particles and the adhesion strength between the plow-shares. Moreover in increasing depth that increases the necessary with drawal requirements to overcome these forces. These results are consistented with the results which were obtained (Al-suhaibani and Gali, 2010; Kim et al., 2020). Also, it was found that the severed share significant outperformed the conventional shares and the spearhead in obtaining the lowest draft force at a rate of (6.99) $\mathrm{kN}$ compared to the remnant of the treatments, That was due to the lack of confrontation of the surface of the severed share through penetration with the lowest resistance and therefore the lowest draft force, but the increase in the draft force of the spearhead share, is due to an increase in its confrontation with the soil further, as a result of the increase in the area of the share facing the soil when penetration with the deep of the share and thus the increase in the draft force, and these results are consistent with what was reached (Alrijabo and Kashmola, 2013) where they confirmed that the draft force increases with an increase in the width of the share. The table shows the outperformed of the soil moisture content interaction (13-15\%) with depth (12-14) $\mathrm{cm}$ significant in obtaining the lowest value of the draft force, which reached (5.83) $\mathrm{kN}$ compared to the remnant of the treatments. The interaction of soil moisture content (13-15\%) with the severed share recorded the lowest significant value of

Table (3): Effect of the studied treatments and their interactions on the draft force $(\mathrm{kN})$

\begin{tabular}{|c|c|c|c|c|c|c|}
\hline \multirow{2}{*}{$\begin{array}{l}\text { Soil } \\
\text { moisture } \\
\text { content } \\
(\%)\end{array}$} & \multirow{2}{*}{$\begin{array}{l}\text { Depth of } \\
\text { tillage } \\
(\mathrm{cm})\end{array}$} & \multicolumn{3}{|c|}{ Share type } & \multirow{2}{*}{$\begin{array}{l}\text { Interaction } \\
\text { the soil } \\
\text { moisture } \\
\text { content with } \\
\text { depth }\end{array}$} & \\
\hline & & Conventional & Spearhead & Severed & & \\
\hline \multirow{2}{*}{$13-15$} & $12-14$ & $5.98 \mathrm{k}$ & $6.47 \mathrm{j}$ & 5.031 & $5.83 \mathrm{~d}$ & \\
\hline & $15-17$ & $7.55 \mathrm{~g}$ & $8.43 \mathrm{e}$ & $6.57 \mathrm{i}$ & $7.52 \mathrm{c}$ & \\
\hline \multirow{2}{*}{$17-19$} & $12-14$ & $7.94 \mathrm{f}$ & $8.92 \mathrm{~d}$ & $6.96 \mathrm{~h}$ & $7.94 \mathrm{~b}$ & \\
\hline & $15-17$ & $10.59 \mathrm{~b}$ & $11.37 \mathrm{a}$ & $9.41 \mathrm{c}$ & $10.46 \mathrm{a}$ & \\
\hline \multirow{2}{*}{$\begin{array}{c}\text { Interaction } \\
\text { soil } \\
\text { moisture } \\
\text { content } \\
\text { with the } \\
\text { share type }\end{array}$} & $13-15 \%$ & $6.77 \mathrm{e}$ & $7.45 \mathrm{~d}$ & $5.80 \mathrm{f}$ & \multirow{2}{*}{$\begin{array}{c}\text { Average soil } \\
\text { soil moisture } \\
\text { content }\end{array}$} & $6.67 \mathrm{~b}$ \\
\hline & $17-19 \%$ & $9.27 \mathrm{~b}$ & $10.15 \mathrm{a}$ & $8.19 \mathrm{c}$ & & $9.19 \mathrm{a}$ \\
\hline \multirow{2}{*}{$\begin{array}{l}\text { Interaction } \\
\text { depth with } \\
\text { the share } \\
\text { type }\end{array}$} & $12-14$ & $6.96 \mathrm{e}$ & $7.69 \mathrm{~d}$ & $5.99 \mathrm{f}$ & \multirow{2}{*}{$\begin{array}{c}\text { Average } \\
\text { tillage } \\
\text { depth }\end{array}$} & $6.88 \mathrm{~b}$ \\
\hline & $15-17$ & $9.07 \mathrm{~b}$ & $9.90 \mathrm{a}$ & $7.99 \mathrm{c}$ & & $8.98 \mathrm{a}$ \\
\hline \multicolumn{2}{|c|}{ Average share type } & $8.01 \mathrm{~b}$ & $8.79 \mathrm{a}$ & $6.99 \mathrm{c}$ & & \\
\hline
\end{tabular}

The lowest value is the best 
the draft force of (5.80) $\mathrm{kN}$ compared to the remnant of the treatments. The interaction between the depth (12-14) $\mathrm{cm}$ and the severed share recorded the lowest significant value of the draft force compared to the remnant of the treatments. The reason is due to what was mentioned previously. It was found through the triple interaction between the soil moisture content (13-15\%) with the depth (12-14) cm and the severed share obtained the lowest significant value of the draft force reached (5.03) $\mathrm{kN}$ compared to the remnant of the treatments.

2- Adhesion strength $\left(\mathbf{k N} / \mathbf{m}^{2}\right)$ : Table (4) shows the outperformed of soil moisture content (13-15\%) in recording the lowest significant value of soil adhesion strength on the surface of the share reached $(0.0316) \mathrm{kN} / \mathrm{m}^{2}$ compared to the soil moisture content (17-19\%), the reason for that is that the increasing of soil moisture content. Moreover, it is accompanied by an increasing in the adhesion strength of the soil on the surface of the working part of the plow, held with the less possible force from the particles of the moist soil, and this leads to gravitating soil particles on the surface of the working part, in turn, they form link wrappers between the working part and the soil, and these results are consistent with the results which were achieved by (Alrijabo and AL.Sheekh, 2018; Abdullah and Ahmed, 2018). The depth (12-14) $\mathrm{cm}$ achieved the lowest significant value of the adhesion strength compared to the depth $(15-17) \mathrm{cm}$, and the reason for this is that the increase in depth cause the share to high soil moisture content, so that the water is held with less force by particles and molecules of the soil, so they are attracted to the surface of any object, which in turn forms wrappers between them and the soil, and as a result increases the soil adhesion strength, and these results are consistent with its findings (Al-Tai, 2013). The severed share achieved the lowest significant value of the adhesion strength and reached $(0.0432) \mathrm{kN} / \mathrm{m}^{2}$ compared to the conventional shares and spearhead share, because the severed share is facing less soil and faces the soil diagonally, which leads to breaking the slate of the soil section and dropping it from the surface of the working part of the share, but the reason for increasing it at the spearhead share, because the share has a larger area, and this means that the confrontation of the share with the soil increases, and thus this increases the adhesion strength. The interaction between the soil moisture content (13-15\%) with the depth (12-14) $\mathrm{cm}$ recorded the lowest adhesion strength compared to the remnant of the treatments. and the interaction between the soil moisture content (13-15\%) with the severed share recorded the lowest value of the adhesion strength compared to the remnant of the treatments, for the same reasons mentioned above. Depth (12-14) $\mathrm{cm}$ with the severed share recorded the lowest adhesion strength compared to the remnant of the treatments. Triple interaction was recorded between the soil moisture content (13-15\%) with the depth (12-14) cm, and the severed share had the lowest adhesion strength, while the soil moisture content (17-19\%) with the depth (15-17) $\mathrm{cm}$ and the spearhead share was recorded highest adhesion strength value. 
Table (4): Effect of the studied treatments and their interactions on the adhesion strength $\left(\mathrm{kN} / \mathrm{m}^{2}\right)$

\begin{tabular}{|c|c|c|c|c|c|c|}
\hline \multirow{2}{*}{$\begin{array}{l}\text { Soil } \\
\text { moisture } \\
\text { content } \\
(\%)\end{array}$} & \multirow{2}{*}{$\begin{array}{l}\text { Depth } \\
\text { of } \\
\text { tillage } \\
(\mathrm{cm})\end{array}$} & \multicolumn{3}{|c|}{ Share type } & \multirow{2}{*}{$\begin{array}{l}\text { Interaction } \\
\text { the soil } \\
\text { moisture } \\
\text { content with } \\
\text { depth }\end{array}$} & \\
\hline & & Conventional & Spearhead & Severed & & \\
\hline \multirow{2}{*}{$13-15$} & $12-14$ & 0.0274 & 0.0271 & 0.0191 & 0.0236 & \\
\hline & $15-17$ & 0.0394 & 0.0449 & 0.0344 & 0.0396 & \\
\hline \multirow{2}{*}{ 17-19 } & $12-14$ & 0.0567 & 0.0609 & 0.0510 & 0.0562 & \\
\hline & $15-17$ & 0.0718 & 0.0734 & 0.0682 & 0.0711 & \\
\hline \multirow{2}{*}{$\begin{array}{c}\text { Interaction } \\
\text { soil } \\
\text { moisture } \\
\text { content } \\
\text { with the } \\
\text { share type }\end{array}$} & $13-15 \%$ & 0.0320 & 0.0360 & 0.0267 & \multirow{2}{*}{$\begin{array}{l}\text { Average } \\
\text { soil } \\
\text { moisture } \\
\text { content }\end{array}$} & $0.0316 \mathrm{~b}$ \\
\hline & $17-19 \%$ & 0.0642 & 0.0671 & 0.0596 & & $0.0637 \mathrm{a}$ \\
\hline \multirow{2}{*}{$\begin{array}{l}\text { Interaction } \\
\text { depth with } \\
\text { the share } \\
\text { type }\end{array}$} & $12-14$ & 0.0407 & 0.0440 & 0.0350 & \multirow{2}{*}{$\begin{array}{c}\text { Average } \\
\text { tillage } \\
\text { depth }\end{array}$} & $0.0399 \mathrm{~b}$ \\
\hline & $15-17$ & 0.0556 & 0.0592 & 0.0513 & & $0.0554 \mathrm{a}$ \\
\hline \multicolumn{2}{|c|}{ Average share type } & $0.0481 \mathrm{~b}$ & $0.0516 \mathrm{a}$ & $0.0432 \mathrm{c}$ & & \\
\hline
\end{tabular}

The lowest value is the best

3- Tillage appearance (number of clods larger than $7.5 \mathrm{~cm})\left(\mathrm{clods} / \mathrm{m}^{2}\right)$ : Table (5) shows the soil moisture content recording (13-15\%) lowest significant value of the number of clods was (12.00) clods $/ \mathrm{m}^{2}$ compared to the soil moisture content (17-19\%), the reason for this is the increase in the soil moisture content which leads to an increasing in the depth of tillage. Moreover, it accompanied by divestiture and excitement of the soil as well as an increase in the number of clods. The increasing in the soil moisture content leads to an increasing in the degree of soil agglomeration and adhesion to each other. There by an increasing in the number of apparent clods. These results are consistent with his findings (Jasim and Saadoon, 2016). The depth (12-14) cm recorded the lowest significant value of the number of clods compared to the depth (15-17) $\mathrm{cm}$, the reason for the increase in the number of clods when increasing the depth is that with increasing depth, large clods appear from below the surface of the soil and have a higher density and rigidity than surface soils as a result of increased soil moisture, which in turn leads to an increase in the cohesion of the soil grains and consequently an increase in the number of clods, and this is consistent with (Al-Talabani et al., 2015; AL-Obaidi, 2018). The results indicated that the severed share significant outperformed. It recorded the lowest number of clods and reached (13.16) clods $/ \mathrm{m}^{2}$ compared to the conventional share and the spearhead share, due to the decrease in the number of clods at the severed share. The share faces the soil at a different angle, which leads to breake the clods which reduces the number it, the severed share recorded the lowest depth of 
tillage and a slight difference. Thus the number of clods was reduced because the lower depth lowest, the number of clods and these are reflected positively on this trait. While the reason for increasing it at the spearhead share is due to the increase in the area of the share facing the soil. As well as the increase in depth, which causes an increase in the number of clods because of the extrusive relationship between the depth and the number of clods increases by increasing the number of clods. The soil moisture content (13-15\%) and depth (12-14) cm outperformed to obtain the lowest significant value for the number of clods compared to other treatments.

Table (5): Effect of the studied treatments and their interactions on a number of clods with a diameter larger than $7.5 \mathrm{~cm}\left(\mathrm{clods} / \mathrm{m}^{2}\right)$

\begin{tabular}{|c|c|c|c|c|c|c|}
\hline \multirow{2}{*}{$\begin{array}{c}\text { Soil } \\
\text { moisture } \\
\text { content } \\
(\%)\end{array}$} & \multirow{2}{*}{$\begin{array}{l}\text { Depth of } \\
\text { tillage } \\
(\mathrm{cm})\end{array}$} & \multicolumn{3}{|c|}{ Share type } & \multirow{2}{*}{$\begin{array}{l}\text { Interaction } \\
\text { the soil } \\
\text { moisture } \\
\text { content with } \\
\text { depth }\end{array}$} & \\
\hline & & Conventional & Spearhead & Severed & & \\
\hline \multirow{2}{*}{$13-15$} & $12-14$ & 10.66 & 12.00 & 10.66 & $10.33 \mathrm{~d}$ & \\
\hline & $15-17$ & 14.00 & 15.00 & 14.00 & $13.67 \mathrm{c}$ & \\
\hline \multirow{2}{*}{$17-19$} & $12-14$ & 15.33 & 17.00 & 15.33 & $15.55 \mathrm{~b}$ & \\
\hline & $15-17$ & 21.00 & 22.33 & 21.00 & $20.44 \mathrm{a}$ & \\
\hline \multirow{2}{*}{$\begin{array}{c}\text { Interaction } \\
\text { soil } \\
\text { moisture } \\
\text { content } \\
\text { with the } \\
\text { share type }\end{array}$} & $13-15 \%$ & 12.33 & 13.50 & 12.33 & \multirow{2}{*}{$\begin{array}{l}\text { Average } \\
\text { soil } \\
\text { moisture } \\
\text { content }\end{array}$} & $12.00 \mathrm{~b}$ \\
\hline & $17-19 \%$ & 18.16 & 19.66 & 18.16 & & $18.00 \mathrm{a}$ \\
\hline \multirow{2}{*}{$\begin{array}{l}\text { Interaction } \\
\text { depth with } \\
\text { the share } \\
\text { type }\end{array}$} & $12-14$ & 13.00 & 14.50 & 13.00 & \multirow{2}{*}{$\begin{array}{c}\text { Average } \\
\text { tillage } \\
\text { depth }\end{array}$} & $12.94 \mathrm{~b}$ \\
\hline & $15-17$ & 17.50 & 18.66 & 17.50 & & $17.05 \mathrm{a}$ \\
\hline \multicolumn{2}{|c|}{ Average share type } & $15.25 \mathrm{~b}$ & $16.58 \mathrm{a}$ & $13.16 \mathrm{c}$ & & \\
\hline
\end{tabular}

The lowest value is the best

The soil moisture content $(13-15 \%)$ with the severed share recorded the lowest value for the number of clods compared to the remnant of the treatments for the reasons mentioned above. The interaction between the depth $(12-14) \mathrm{cm}$ with the severed share showed the lowest value for the number of clods compared with the depth (15-17) $\mathrm{cm}$ and the spearhead share, which recorded the highest value for the number of clods. The triple interaction between the soil moisture content (13-15\%) with the depth (12-14) cm and the severed share recorded the lowest value for the number of clods compared to the remnant of the treatments.

4- Vertical deviation ratio (\%): Table (6) shows the recording of soil moisture content (13-15\%), the lowest significant value of the vertical deviation ratio was $(2.755 \%)$ compared to the soil moisture content (17-19\%), the reason for that to the fact that soil resistance to penetration of plow-share is reduced by increasing soil 
moisture before tillage, as the act of deeper increased in the soil under the states of tillage itself, which means that increased soil moisture leads to an increase in the value of the evidence of the irregular depth of tillage, and these results are consistent with the results obtained (AL.Sheekh, 2018). The depth (15-17) cm recorded the lowest significant value of the vertical deviation ratio $(2.446 \%)$ compared to the depth $(12-14) \mathrm{cm}$, and the reason for this is due to the direct relation between vertical stability and the depth of tillage, as the increased the depth, the higher the stability due to the lack vertical pressure projected at this depth, which caused a decrease in the rate of vertical deviation, this is consistent with the results found (Abdullah and Shaheen, 2018). It was also found that the spearhead share was significant outperformed to the conventional and severed shares in obtaining the lowest value for the vertical deviation ratio, due to the increase in the act of deeper and penetration by the spearhead share, which reflected positively on the increase in vertical stability, that is, with the increase in depth the vertical stability increases and thus decreases the vertical deviation ratio because of the relation between them is direct, as for the reason for their increase at the severed share, it is due to a decrease in depth a little, and thus the vertical stability decreases and thus the vertical deviation ratio increases somewhat. The interaction between the soil moisture content (13-15\%) with the depth (15-17) cm resulted in obtaining the lowest value for the vertical deviation ratio compared to other treatments. The soil moisture content (13-15\%) with the spearhead share recorded the lowest value

Table (6): Effect of the studied treatments and their interactions on the vertical deviation ratio $(\%)$

\begin{tabular}{|c|c|c|c|c|c|c|}
\hline \multirow{2}{*}{$\begin{array}{l}\text { Soil } \\
\text { moisture } \\
\text { content } \\
(\%)\end{array}$} & \multirow{2}{*}{$\begin{array}{l}\text { Depth of } \\
\text { tillage } \\
(\mathrm{cm})\end{array}$} & \multicolumn{3}{|c|}{ Share type } & \multirow{2}{*}{$\begin{array}{l}\text { Interaction } \\
\text { the soil } \\
\text { moisture } \\
\text { content with } \\
\text { depth }\end{array}$} & \\
\hline & & Conventional & Spearhead & Severed & & \\
\hline \multirow{2}{*}{$13-15$} & $12-14$ & $3.156 \mathrm{de}$ & $3.077 \mathrm{e}$ & $3.282 \mathrm{c}$ & 3.171 & \\
\hline & $15-17$ & $2.317 \mathrm{~h}$ & $2.277 \mathrm{~h}$ & $2.421 \mathrm{~g}$ & 2.338 & \\
\hline \multirow{2}{*}{$17-19$} & $12-14$ & $3.402 \mathrm{~b}$ & $3.186 \mathrm{~cd}$ & $3.725 \mathrm{a}$ & 3.437 & \\
\hline & $15-17$ & $2.604 \mathrm{f}$ & $2.525 \mathrm{f}$ & $2.534 \mathrm{f}$ & 2.554 & \\
\hline \multirow{2}{*}{$\begin{array}{c}\text { Interaction } \\
\text { soil } \\
\text { moisture } \\
\text { content } \\
\text { with the } \\
\text { share type }\end{array}$} & $13-15 \%$ & 2.736 & 2.677 & 2.851 & \multirow{2}{*}{$\begin{array}{l}\text { Average } \\
\text { soil } \\
\text { moisture } \\
\text { content }\end{array}$} & $2.755 \mathrm{~b}$ \\
\hline & $17-19 \%$ & 3.003 & 2.855 & 3.129 & & $2.996 \mathrm{a}$ \\
\hline \multirow{2}{*}{$\begin{array}{l}\text { Interaction } \\
\text { depth with } \\
\text { the share } \\
\text { type }\end{array}$} & $12-14$ & $3.279 \mathrm{~b}$ & $3.131 \mathrm{c}$ & $3.503 \mathrm{a}$ & \multirow{2}{*}{$\begin{array}{c}\text { Average } \\
\text { tillage } \\
\text { depth }\end{array}$} & $3.304 \mathrm{a}$ \\
\hline & $15-17$ & $2.460 \mathrm{de}$ & $2.401 \mathrm{e}$ & $2.477 \mathrm{~d}$ & & $2.446 \mathrm{~b}$ \\
\hline \multicolumn{2}{|c|}{ Average share type } & $2.869 \mathrm{~b}$ & $2.766 \mathrm{c}$ & $2.990 \mathrm{a}$ & & \\
\hline
\end{tabular}

The lowest value is the best 
of the vertical deviation ratio, compared to the remnant of the treatments. The interaction between the depth (15-17) $\mathrm{cm}$ with the spearhead share was the lowest significant value of the vertical deviation ratio compared with the remnant of the treatments was recorded. The triple interaction between the soil moisture content $(13-15 \%)$ with the depth $(15-17) \mathrm{cm}$ and the spearhead share recorded the lowest significant value of the vertical deviation ratio compared to the remnant of the treatments.

\section{CONCLUSION}

We conclude from this study that the best combination of the performance of the machine unit was when using the soil moisture content (13-15\%) with Plowing depth (12-14) cm and the severed share designed and manufactured locally, as the lowest draft force, adhesion strength and the number of clods were obtained accordingly.

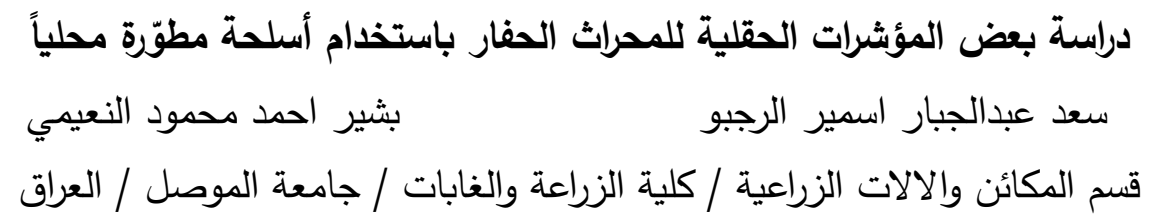

E-mail: saad21955mech@gmail.com

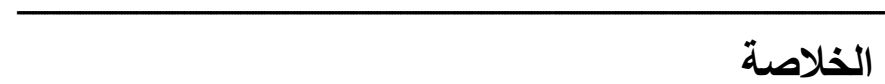

أجريت تجربة حقلية في أحد الحقول التابعة لمحافظة نينوى في تربة نسجتها مزيجة غرينية تحت نظام

الري بالرش المحوري ، حيث تضمن البحث مستويين من رطوبـة التربـة (13-15\%) و (17-19\%) وعمقين للحراثة (12-14) سم و (15-17) سم وثلاثة أنواع من اسلحة المحراث الحفار (السلاح التقليدي ، السـلاح رأس الرمح والسلاح المقطوع) وتأثير ذلك في بعض المؤشرات الحقلية التالية (قوّة السحب ، قوة التصـاق التربة

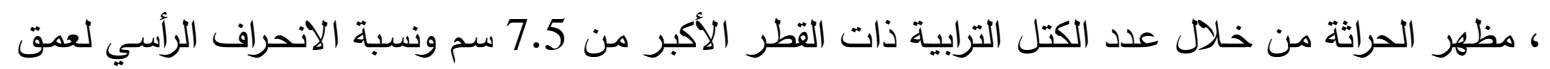
الحراثة) ـ نفذت التجربـة وفق تصـيم القطاعـات العشوائية الكاملـة تحت نظـام الالكواح المنشقة - المنشقة.

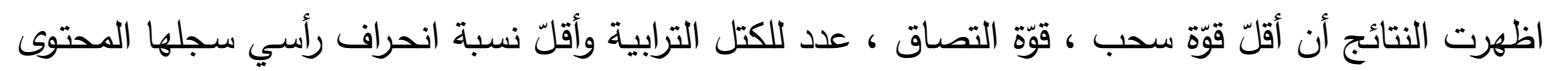
الرطوبي (13-15\%) ، كمـا سـل العمـق (12-14) سم أقلّ قوّة سـب ، قوّة التصـاق وأقلّ عدد للكتل الترابية ، في حين تفوّق العمق (15-17) سم في حصوله على أقلّ نسبة انحراف رأسي ، وتقوّق السـلاح المقطوع في تسجيل أقلّ قوّة سحب ، قوّة التصاق وأقلّ عدد للكتل الترابية ، في حين تفوّق السلاح رأس الرمح

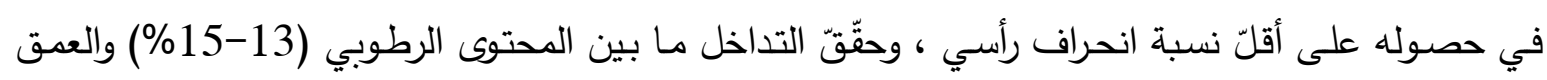

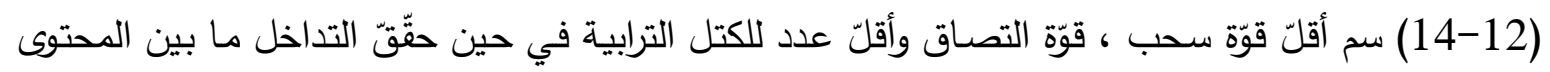
الرطوبي (13-15\%) والعمق (15-17) سم أقلّ نسبة انحراف رأسي . الكلمات الدالة : المحراث الحفار ، سلاح القطع ، التصاق التربة ، قوّة السحب ، الدبه ، الاتحراف الرأسي . 


\section{REFERENCES}

Abdullah, Adel Ahmed and Ahmed Ibrahim Abde Shaheen (2018). Assessment performance of two types of assistance parts (landsides) locally made and traditional for moldboard plow under effect deep tillage in some indecators mechanical performance. Mesopotamia Journal of Agriculture, 46(4):243256.

Abdullah, Adel Ahmed and Ziad Saleh Ahmed (2018). Designing and manufacturing landside by different length of moldboard plow and studying effect in some notes of field performance under two levels of moisture Mesopotamia Journal of Agriculture, 46(1):191-202.

Adai, Shaker Hantoush (2016). Tractors Performance Mechanics. part 1, Dar AlKafeel For printing, Publishing And Distribution, Basra University, Iraq.

AlBanna, Aziz Ramo (1990). Soil Tillage Equipment. Dar Al-Kutub Printing And Publishing Directorate, Mosul University, Ministry of Higher Education and Scientific Research.

AL-Obaidi, Yahya Younis Mohsin (2018). Evaluation Of Heavy Chisel Plow Performance In Different Speeds In Terms Of Some Mechanical Performance Indicators. Master Thesis, Department of Agricultural Machinery And Equipments, College of Agriculture And Forestry, University Of Mosul.

Alrijabo, Saad Abdul Jabbar and Sinan Bashar Younis Kashmola (2013). Design effect of shank shape and the developed blade type for chisel plow on some of power requirement. Tikrit Journal For Agricultural Sciences, 13(2):269-278.

Alrijabo, Saad Abdul Jabbar and Thanoon Younis AL.Sheekh Ali (2018). Effect of added weights for agricultural tractor under two levels of moisture in some mechanical properties using the moldboard plow. Mesopotamia Journal of Agriculture, 46(4):281-292.

Al-Sheekh Ali, Thanoon Youns Hussein Ali (2018). Effect Of Added Weights On Agricultural Tractor Wheels (M.F.285S) In Some Mechanical Properties Under Different Moisture Conditions By Using The Moldboard Plow. Master Thesis, Department of Agricultural Machinery and Equipment, College Of Agriculture And Forestry, University Of Mosul.

Al-Suhaibani, Ahmed Mohamed and Ali Nasser Wehbe (1985). Principles Of Agricultural Machinery. Translator, King Saud University, Kingdom Of Saudi Arabia.

AL-suhaibani, S.A. and A.E Ghaly (2010). Effect of tillage depth of tillage and forward speed on the performance of a medium size chisel plow operating in a sandy soil. American Journal Of Agricultural And Biological Sciences, 5 (3): 247-255.

Al-Tai, Yasser Fazaa Mahmoud Mohamed, (2013). Compared of Performance of Some Types of Plows in The Mechanical and Physical Characteristics of The 
Soil. Master Thesis, Department of Agricultural Machinery And Equipment, College Of Agriculture And Forestry, University Of Mosul.

Al-Talabani, Jinan Hikmat Namik (2008). The effect of smoothing systems and organic residues on the number of blocks with a diameter greater than $5 \mathrm{~cm} / \mathrm{m}^{2}$ and some physical soil characteristics. Iraqi Journal Of Soil Science, 8(1): 102-110.

Al-Talabani, Jinan Hikmat Namik, Turki Muftin Saad and Abdul Sttar Muhammad Ali Al-Jasem (2015). Effects of soil moisture and tillage depth interaction on some tillage indicators using triple disc plow. Iraqi Journal of Soil Science, 15(1): 18-25.

Bernacki, H. , J. Haman and C.Z. Kanafojski. (1972). Agricultural Machines Theory And Construction. Vol.(1), Spring Field, 111: Nat, Technical Information Service.

Dawood, Khaled Muhammad and Zaki Abd Elias (1990). Statistical Methods For Agricultural Research. Dar Al-Kutub For printing And publishing, University Of Mosul, Ministry Of Higher Education And Scientific Research.

Grisso, R.D., J.V. Perumpral and F.M. Zoz (2007). Spreadsheet for matching tractors and drawn implements. Applied Engineering In Agriculture, 23(3): 259-265.

Jasim, Abdulrazzak A. and Salam F. Saadoon (2016). Using locally for different tillage equipment under two levels of soil moisture. Elixir International Journal Mechanical Engineering, 99 (2016) 43096-43099.

Jebur, Hussain A. and Yasir A. A. Alsayyah (2017) . Study of the soil moisture content and the tractor speed on the performance efficiency of the machinery unit . Journal Of Agriculture And Veterinary Science, 10(5):65-70.

Kim, Yeon-Soo, Taek-Jin Kim, Yong-Joo Kim, , Sang-Dae Lee, Seong-Un Park and Wan-Soo Kim (2020). Development of a real-time tillage depth measurement system for agricultural tractors: application to the effect analysis of tillage depth on draft force during plow tillage. Sensors 2020, 20(3), 912; https://doi.org/10.3390/s20030912

Manuwa, S.I. and O.C.Ademosun,.(2007). Draught and soil disturbance of model tillage tines under varying soil parameters. Agricultural Engineering International: IX(January 2007),1-18 http//www. Cigrjournal.org /index.php/ Ejounral/ article / view/843/837. The CIGR E Journal.

Mustafa, Mubarak Muhammad and Issam Ahmed Al-Sahar (2007). Agricultural Mechanization, Open Education Center, Faculty Of Agriculture For Printing And Publishing, Ain Shams University, Arab Republic Of Egypt. 